\title{
Mempersiapkan Petani Muda dalam Mencapai Kedaulatan Pangan
}

\section{Sostenes Konyep ${ }^{1 *}$}

${ }^{1}$ Balai Pengkajian Teknologi Pertanian Papua Barat

\begin{tabular}{l}
\hline \multicolumn{1}{c}{ ARTIKEL INFO } \\
\hline Sejarah artikel \\
Diterima $18 / 04 / 2021$ \\
Diterima dalam bentuk revisi 16/05/2021 \\
Diterima dan disetujui 04/06/2021 \\
Tersedia online 22/06/2021 \\
\hline Kata kunci \\
Kedaulatan pangan \\
Maju \\
Mandiri \\
Modern \\
Petani milenial \\
\hline
\end{tabular}

\begin{abstract}
ABSTRAK
Kedaulatan pangan adalah kemampuan suatu bangsa untuk: 1) mencukupi kebutuhan pangan dari produksi dalam negeri, 2) mengatur kebijakan pangan secara mandiri, serta 3) melindungi dan mensejahterakan petani sebagai pelaku utama usaha pertanian pangan. Demi mewujudkannya harus menggerakkan pemuda sebagai aset penting sebagai motor penggerak. Namun sangat ironi karena banyak generasi muda kita meninggalkan sektor pertanian dan bekerja pada sektor lain. Oleh karena itu harus ada langkah-langkah konkret pemerintah dan semua komponen yang peduli sehingga menghindari krisis pangan kemudian harapan kedaulatan pangan dimasa depan dapat terwujud. Tujuan penulisan artikel ini adalah merumuskan strategi mempersiapkan petani-petani muda dalam mencapai kedaulatan pangan berdasarkan berbagai kajian pustaka dan hasil penelitian. Metode analisis data dilakukan secara deskriptif tentang peran setiap insan pertanian dalam mempersiapkan generasi muda pertanian untuk mencapai swasembada pangan. Strategi itu tersebut dimulai dari perubahan pola pikir generasi muda tentang pertanian bermula dengan memberi informasi yang benar tentang pertanian dan dunia pertanian itu menarik; lembaga pendidikan dari TK-Perguruan Tinggi wajib memiliki lahan untuk pertanian dan guru yang membidangi pertanian; rekruitmen mahasiswa dari setiap desa yang berpotensi pertanian dan pemberian beasiswa bagi yang tidak mampu namun berprestasi; menggalakkan program mari membangun desa dan menyiapkan sarana/prasarana pendukungnya; mendorong pembentukan kelompok-kelompok masyarakat dan pembinaannya oleh pemerintah atau lembaga swadaya masyarakat; mendorong program pekarangan pangan lestari dan sarana produksi yang mudah diakses.
\end{abstract}

C2021 Politeknik Pembangunan Pertanian Manokwari 


\section{ABSTRACT}

Food sovereignty is the ability of a nation to: 1) fulfill food needs from domestic production, 2) regulate food policies independently, and 3) protect and prosper farmers as the main actors in the food agriculture business. To make it happen, youth must be mobilized as an important asset as a driving force. However, it is very ironic because many of our young people leave the agricultural sector and work in other sectors. Therefore, there must be concrete steps from the government and all concerned components so as to avoid a food crisis and the hope offood sovereignty in the future can be realized. The purpose of writing this article is to contribute ideas in the form of strategies to prepare young farmers in achieving food sovereignty. The data analysis method is carried out descriptively about the role of every agricultural person in preparing the agricultural millennial generation who can seize

\section{PENDAHULUAN}

Nawacita atau agenda prioritas Kabinet Kerja pemerintahan Jokowi-JK adalah mengarahkan pembangunan pertanian untuk mewujudkan kedaulatan pangan, agar Indonesia sebagai bangsa dapat mengatur dan memenuhi kebutuhan pangan rakyatnya secara berdaulat. Renstra Kementan 2015-2019 menerjemahkan kedaulatan pangan sebagai bentuk kemampuan bangsa dalam hal : 1) mencukupi kebutuhan pangan dari produksi dalam negeri, 2) mengatur kebijakan pangan secara mandiri, serta 3) melindungi dan mensejahterakan petani sebagai pelaku utama usaha pertanian pangan. Kedaulatan pangan harus dimulai dari swasembada pangan secara bertahap diikuti dengan peningkatan nilai tambah usaha pertanian secara luas untuk meningkatkan kesejahteraan petani.

Dalam mewujudkan kedaulatan pangan, pemuda adalah salah satu aset penting yang menjadi motor penggerak dalam mendukung agenda Nawacita karena ditangan pemudalah tongkat estafet kepemimpinan bangsa ini business opportunities in achieving food selfsufficiency. This strategy starts from a change in the mindset of the younger generation about agriculture, starting with providing correct information about agriculture and the world of agriculture is interesting; educational institutions of kindergartentertiary institutions are required to have land for agriculture and teachers in charge of agriculture; recruitment of students from every village with agricultural potential and providing scholarships for the poor but with good achievements; promote the village marijuana building program and prepare supporting facilities / infrastructure; encourage the formation of community groups and their development by the government or nongovernmental organizations; encouraging sustainable food yards and easily accessible production facilities.

digantungkan. Regenerasi adalah sebuah keniscayaan yang tidak bisa ditolak atau dihindari. Bangsa manapun yang ingin tetap berjaya dan bertahan dalam bidang pertanian pasti akan menyiapkan keberlanjutan regenerasinya yang mencintai pertanian dan lingkungannya.

Sementara itu generasi muda kita cenderung meninggalkan pedesaan/pertanian untuk bekerja pada sektor lain. Sektor pertanian menjadi kurang diminati generasi muda, banyak lulusan pertanian yang pindah haluan. Generasi muda adalah generasi yang belum memiliki banyak pengalaman walau sebagai anak petani belum tentu terlibat dalam pertanian (Nazaruddin dan Anwarudin, 2019; Anwarudin, et al., 2020a; Anwarudin, et al., 2020b). Faktor pendorong mobilitas petani dari desa ke kota dan lebih memilih menjadi tenaga kerja di luar negeri karena kondisi sosial ekonomi lemah dan pendidikan yang terbatas (Chotib, 2007 dalam Arvianti et al., 2005).

Menurut pusat data dan informasi pertanian 2020, penduduk berumur 15 tahun ke 
atas yang bekerja di sektor pertanian sempit $27,86 \%$, pertanian lainnya $2,35 \%$ sedangkan yang bekerja di non pertanian sekitar 71,32\% dari sekitar 128.454.184 angkatan kerja dan 9.767754 pengangguran. Selain itu, Bappenas memproyeksikan bahwa tahun 2063, tidak ada petani di Indonesia karena 3 hal: a) para petani beralih ke sektor jasa dan industri. Pekerja di sektor pertanian menurun dari $65,8 \%$ di tahun 1976 turun menjadi $28 \%$ di tahun 2019, b) alih fungsi lahan, dalam kurun waktu 6 tahun terakhir dimana tahun 2019 menyisakan 7,45 juta hektar lahan pertanian, c) meningkatnya laju urbanisasi, diprediksi tahun 2045 jumlah penduduk yang tinggal dikota mencapai $67,1 \%$ atau setara 68,3 juta orang.

Dikhawatirkan akan terjadi krisis pangan akibat ketidak seimbangan antara ketersediaan bahan pangan dengan jumlah penduduk. Kelangkaan bahan pangan dapat menyebabkan kenaikan harga pangan. FAO menyebutkan bahwa diperkirakan sekitar 36 negara mengalami peningkatan harga pangan yang cukup tajam berkisar dari 75\%-200\%. Akibat krisis pangan dapat mengakibatkan terjadinya gejolak sosial dan politik seperti yang di alami Somalia tahun 2008. Disamping itu pengangguran akan meningkat. Oleh karena itu tulisan ini bertujuan memberikan sumbangsih pemikiran berupa ide dan gagasan bagi pengambil kebijakan dan setiap komponen bangsa yang peduli tentang permasalahan yang akan dihadapi bangsa kita terkait dengan pertanian masa depan.

Metode yang digunakan dalam menganalisis adalah secara deskriptif dengan mengupas kiat-kiat yang perlu dilakukan dalam mempersiapkan petani muda dimasa depan sehingga pencapaian swasembada pangan diharapkan dapat tercapai.

\section{Regenerasi Petani}

Mengingat sebagian besar sumberdaya manusia pertanian berada pada posisi tua, (aging) baik karena dinilai rendah (under value) maupun ditinggal migrasi oleh generasi muda (brain drain) maka regenerasi sektor pertanian penting untuk diperhatikan. Faiz (2007), Adebayo (2010), Johnson (2009) dan Kupets (2011) dalam Setiawan et al., 2015), menyatakan brain drain bukan hanya menyebabkan tuanya umur petani tetapi juga kosongnya SDM berkualitas sektor pertanian di desa.

Regenerasi petani disama artikan dengan suksesi (farm succession) (Zagata dan Sutherland, 2015) dan pewarisan usaha pertanian (farm inheritance) (Leonard et al., 2017). Regenerasi petani dilakukan untuk mengganti usia petani yang tidak produktif lagi (Sottomayor dan Tranter, 2011). Proses menghadirkan pengganti pelaku usaha pertanian secara konsisten (Zagata dan Sutherland, 2015; Leonard et al., 2017 dalam Anwarudin et al., 2020c). Prasyarat terwujudnya keberlanjutan pembangunan pertanian adalah regenerasi petani (Anwarudin et al., 2018 dalam Junaedi et al., 2020).

Data BPS 2020, hasil sensus penduduk jumlah penduduk Indonesia mencapai 270,20 juta bertambah 32,56 juta dibanding sensus penduduk 2010 dengan laju pertumbuhan penduduk $1,25 \%$ juta jiwa dengan $44 \%$ 
penduduknya berada di desa sedangkan $56 \%$ berada di kota. Sehingga dengan bertambahnya jumlah penduduk maka permintaan bahan pangan untuk memenuhi kebutuhan hidup dan gizi masyarakat akan semakin meningkat. Sementara itu kapasitas ketersediaan lahan semakin berkurang akibat konversi lahan yang cukup tinggi untuk kebutuhan perumahan dan industri. Petani muda semakin berkurang sedangkan generasi tua kita sudah tidak mungkin lagi kembali kesawah atau ladang karena sudah tentu tenaganya sudah berkurang. Oleh sebab itu regenerasi petani yang mencintai pertanian dan lingkungannya adalah kebutuhan yang perlu diperhatikan semua yang peduli dengan pertanian Indonesia.

Menurut data Susenas tahun 2020 terdapat sekitar 64,50 juta jiwa penduduk Indonesia yang berada dalam kelompok umur pemuda. Pada tahun 2020, sekitar 23,86\% persen pemuda mengisi seperempat dari total penduduk Indonesia. Dari tahun 2011-2020 persentasi pemuda turun sekitar $2 \%$ poin.

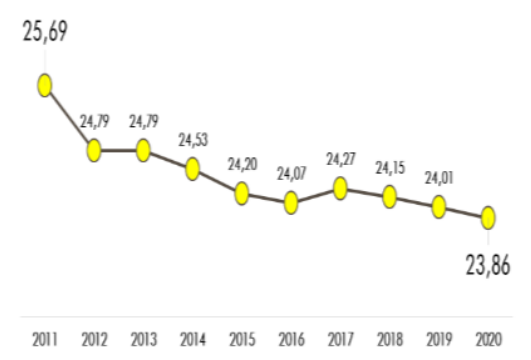

Gambar 1. Presentasi Pemuda Indonesia 20112020 (BPS, 2020)

Indonesia dalam tahun 2020-2035 akan menikmati suatu era yang langka dimana jumlah usia produktif diproyeksikan berada pada grafik tertinggi dalam sejarah bangsa ini yaitu mencapai $64 \%$ dari total jumlah penduduk
Indonesia sebesar 297 juta jiwa. Ini menjadi suatu peluang yang sangat strategis bagi suatu negara untuk dapat melakukan percepatan pembangunan ekonomi karena dukungan sumberdaya manusia produktif dalam jumlah yang cukup signifikan.

\section{Perubahan Pola Pikir tentang Pertanian}

\section{Berkelanjutan}

Pola pikir atau mindset adalah kepercayaan (belief) atau sekumpulan kepercayaan (set of belief) atau cara berpikir yang mempengaruhi perilaku (behaviour) dan sikap (attitude) seseorang yang akhirnya menentukan level keberhasilan (nasib) hidupnya (Adi, 2011 dalam Khuzaeva, 2014) Tantangan ke depan adalah bagaimana mengubah pola pikir generasi muda kita terhadap pertanian, bahwa masih banyak potensi pertanian yang belum dimanfaatkan secara optimal.

Proses pembentukan pola pikir terbentuk sepanjang umur kita. Awal terbentuk sudah dimulai sejak dalam kandungan. Kemudian, proses itu berlanjut pada saat bayi, anak-anak, remaja, pemuda, dewasa bahkan sampai tua. Salah satu unsur penting pembentukan pola pikir adalah informasi. Ini dapat berupa pemikiran yang dibungkus dalam nasihat orang tua, guru, orang lain, atau pemikiran dari para elit, pembicara terkenal, sahabat dekat, abang, adik, atau saudara. Ini juga bisa berupa pemikiran-pemikiran yang didapat dari buku, surat kabar, majalah, inspirasi dari film, sejarah, berita dari teleivisi atau media elektronik lainnya. 
Menurut White (2011), ketika ingin memahami pemuda sebagai generasi penerus, maka kita harus memahami pendekatan relasional. Maksudnya, pemuda harus dilihat dari dinamika hubungan pemuda dengan orang lain (orang dewasa) dalam struktur yang lebih besar dari reproduksi sosial. Dengan konsep ini menunjukan bahwa orang lain yang ada di sekitar pemuda akan berpengaruh terhadap tindakan dan keputusan pemuda termasuk keputusan untuk terlibat dalam bidang pertanian atau mencari pekerjaan di sektor lain. Pihak-pihak tersebut adalah orang tua, teman sebaya dan masyarakat sosial pemuda tersebut bergaul. Orang tua merupakan orang yang paling dekat dengan pemuda. Hampir semua tindakan dan perilaku anak sangat dipengaruhi oleh orang tua, termasuk salah satunya pengajaran orang tua untuk bekerja disektor pertanian. Demikian pula dengan teman sebaya, sebagai pihak yang sering bergaul dan berbagi pikiran dengan pemuda.

Pertanian adalah kegiatan pemanfaatan sumber daya hayati yang dilakukan manusia untuk menghasilkan bahan pangan, bahan baku industri atau sumber energi serta untuk mengelola lingkungannya. Salah satu cara untuk menarik orang muda kita dalam bertani menurut pakar pertanian yang adalah dengan mengubah citra bahwa sektor pertanian, peternakan dan perikanan juga bernilai ekonomi tinggi, pertanian itu tidak hanya terjun langsung untuk bercocok tanam tetapi ada juga sektor diluar sawah ladang yang menjanjikan secara finansial misalnya usaha penggilingan, peningkatan kualitas produk dan pemasaran.
Oleh karena itu, upaya yang dapat dilakukan untuk meningkatkan daya tarik generasi muda pada sektor pertanian adalah menyebar luaskan arus informasi pertanian melalui media cetak atau elektronik. Membangun pertanian dalam konteks industri yang sarat dengan inovasi dan teknologi yang menangani hulu hingga hilir akan memberikan peluang yang besar dalam menghasilkan aneka produk pertanian yang bernilai ekonomi tinggi. Pendekatan bioindustri pertanian menjadi sangat penting dan strategis untuk mewujudkan upaya tersebut

Pertanian berkelanjutan adalah sebuah sistem pertanian yang terpadu yang secara berangsur-angsur meningkatkan penghasilan tiap satuan lahan dan mempertahankan keutuhan dan keanekaragaman ekologi dan hayati sumberdaya alam yang ada secara jangka panjang, memberikan keuntungan ekonomi bagi tiap orang menyumbang peningkatan mutu kehidupan dan memperkuat pembangunan ekonomi negara (Notohaprawiro, 2006 dalam Ningsih dan Sjaf, 2015; Makabori \& Tapi, 2019)

Tujuan pertanian berkelanjutan menurut Menteri Pertanian saat memberikan sambutan pada pertemuan Governing Council ke-11 CAPSA (The Centre For The Alleviation of Poverty Through Sustainable Agriculture) Tanggal 12 Februari 2015 di Bogor adalah mengatasi kemikinan di desa dan daerah tertinggal (Widayadi, 2015 dalam Virianita et al., 2019).

Menurut peneliti dari Pusat Penelitian Kependudukan, Lembaga Ilmu Pengetahuan Indonesia, perlu adanya pendidikan tentang 
teknologi dan variasi teknik budidaya pertanian berkelanjutan bagi para pemuda. Teknik budidaya yang berkelanjutan ini akan mengurangi ketergantungan petani pada penggunaan pupuk kimia dan lebih adaptif terhadap perubahan lingkungan. Selain itu profesi petani juga harus diberikan insentif oleh pemerintah. Pakar pertanian yang juga Dekan Fakultas Pertanian Universitas Gajah Mada, Jamhari; menuturkan lembaga akademik berperan dalam menyiapkan generasi muda petani milenial agar bisa mengambil posisi di masa depan.

\section{Generasi yang Mencintai Pertanian dan}

\section{Lingkungan}

Sebatang pohon yang masih muda dapat dibelokkan kebentuk mana saja yang diinginkan, dan kalau dibiarkan pohon muda itu akan bertumbuh sebagaimana yang telah bengkokkan, dan menjadi pohon yang salah bentuk karena telah menjadi cacat dan menderita. Kita boleh sesudah bertahun-tahun pertumbuhan berusaha untuk meluruskan pohon itu, tetapi segala usaha akan terbukti siasia. Inilah kasus yang sama dengan pikiran anak-anak. Mereka harus dilatih dengan sangat hati-hati dan teliti pada masa anak-anaknya. Kebiasaan yang dibentuk pada masa muda akan bertumbuh dengan pertumbuhan dan dikuatkan dengan kekuatan, demikian untuk seterusnya, hanya akan bertumbuh lebih kuat.

Persiapan harus dibuat sekarang untuk pendidikan dalam skala yang lebih besar. Sekolah-sekolah harus membangun usaha yang berhubungan dengan pertanian dan tehnik, harus ada guru-guru yang mengajarkannya.
Kalau saja ada pengembangan pertanian dan tehnik di sekolah-sekolah kita, dan seandainya ada guru-guru yang dipekerjakan untuk mendidik orang muda dalam mata pelajaran mengenai bagaimana belajar dan bekerja, menyediakan sebagian waktu dari setiap harinya untuk perbaikan mental, dan sebagian lagi untuk perbaikan fisik, maka akan ada kelas orang muda yang lebih bermutu untuk mencapai tingkat kemampuan dalam melakukan tindakan yang mempengaruhi pembentukan masyarakat. Maka orang muda kita akan memiliki keteguhan, sabar menanggung segala sesuatu dan berani mengalahkan halangan - halangan; prinsipprinsip semacam ini tidak akan digoyahkan oleh pengaruh-pengaruh yang salah.

Langkah konkrit yang perlu dilakukan dalam mempersiapkan sumber daya manusia generasi muda adalah : (a) pemerintah agar mendorong sekolah-sekolah dari TK sampai SMU menerapkan kurikulum tentang pertanian dan lingkungan dengan prosentase $70 \%$ praktik serta $30 \%$ teori, (b) menjaring siswa baru untuk dididik di sekolah-sekolah tinggi lingkup pertanian (Politeknik Pembangunan Pertanian dan Politeknik Enjinering Pertanian) dan pemberian beasiswa bagi mahasiswa yang tidak mampu namun berprestasi dari tiap kabupaten/kota, (c) revitalisasi sarana dan prasarana belajar mengajar termasuk peningkatan SDM pengajar adalah upaya-upaya yang perlu dilakukan. 
Perubahan Sosial dan Membangun Desa

\section{Mulai dari Belakang}

Perubahan sosial dan pembangunan desa mulai dari belakang (bottom up) merupakan salah satu strategi untuk membangun Indonesia karena pembangunan dari depan (top down) sering kali tidak mencerminkan keinginan masyarakat akar rumput (grass root). Konsep ini bukan hal yang baru, bahkan istilah ini sudah menjadi jargon yang banyak dibicarakan atau disinggung diberbagai seminar. Kalangan birokrasi di negara sedang berkembang termasuk Indonesia masih segan menyebutnya karena istilah ini bagi sebagian orang berkonotasi sosialis revolusioner. Tetapi sudah banyak yang menerjemahkannya secara parsial dengan istilah teknis "perencanaan dari bawah" atau aspirasi masyarakat (Rahardjo dalam Chambers, 1988).

a. Perubahan Sosial

Apakah perubahan sosial itu? Perubahan sosial adalah proses dimana terjadi perubahan struktur dan fungsi suatu sistem sosial. Contoh perubahan sosial adalah pembentukan kelompok pemuda tani. Perubahan baik pada fungsi maupun struktur sosial akan terjadi akibat kegiatan-kegiatan yang terkait dengan kelompok pemuda tani. Struktur suatu sistem terdiri dari berbagai status individu dan status kelompok yang teratur. Berfungsinya status itu merupakan seperangkat peranan atau perilaku nyata seseorang dalam status tertentu. Status dan peranan saling mempengaruhi satu sama lain (Rogers dan Shoemaker dalam Hanafi, 1986).

Nilai-nilai sosial, pola perilaku organisasi, susunan lembaga masyarakat, lapisan dalam masyarakat, kekuasaaan dan wewenang serta interaksi sosial dapat dipengaruhi oleh perubahan-perubahan yang terjadi dalam masyarakat (Soekanto dan Soerjono, 1994 dalam Rosana, 2011)

$$
\text { Inti perubahan sosial adalah }
$$
pembangunan (development). Ada yang menyamakan konsep tentang pembangunan dengan modernisasi. Dengan demikian pembangunan (development) adalah the passing of a traditional society into a modern one (beralihnya masyarakat tradisional menjadi masyarakat modern) yaitu, rekayasa sosial untuk mengubah masyarakat tradisional menjadi masyarakat modern. Development berkisar pada bagaimana mengubah suatu masyarakat dengan mengubah sistem ekonominya.

b. Pembangunan Desa Mulai dari Belakang

Kemiskinan kini menjadi suatu identitas yang melekat dengan pedesaan seperti warisan turun temurun, sehingga tidak heran jika banyak penduduk desa yang mengadu nasib kekota untuk peningkatan taraf hidup keluarganya. Adalah bukan perkara mudah untuk mengatasi persoalan kemiskinan karena banyaknya permasalahan yang saling terkait oleh karena itu perlu perhatian pemerintah dan masyarakat itu sendiri untuk keluar dari kemiskinan. Tabel 2 memperlihatkan persentase pemuda di kota lebih tinggi dibandingkan di desa. 
Tabel 2. Persentase pemuda bekerja menurut sektor usaha utama dan tipe daerah (BPS, 2020)

\begin{tabular}{lcccc}
\hline \hline \multirow{2}{*}{$\begin{array}{c}\text { Karakteristik } \\
\text { Demografi }\end{array}$} & \multicolumn{3}{c}{ Lapangan Usaha Utama } & \multirow{2}{*}{ Total } \\
\cline { 2 - 4 } \multicolumn{1}{c}{$(1)$} & Pertanian & Manufaktur & Jasa-jasa & \\
\hline Total & $(2)$ & $(3)$ & $(4)$ & $(5)$ \\
Tipe Daerah & 20,62 & 24,08 & 55,31 & 100,00 \\
Perkotaan & & & & \\
Perdesaan & 6,19 & 26,51 & 67,30 & 100,00 \\
& 39,41 & 20,90 & 39,68 & 100,00
\end{tabular}

Disamping itu beberapa hal penting yang harus dipersiapkan didesa antara lain: (a) membangun dan memperbaiki infrastruktur pertanian didesa, (b) perlu peningkatan kapasitas SDM generasi muda pertanian yang lebih baik, (c) mendorong kebijakan dan regulasi yang tepat terutama dalam kaitan dengan kepastian mendapat lapangan kerja yang sesuai dengan keahlian dan ketrampilan para generasi muda.

Pemberdayaan petani di beberapa negara telah meningkatkan kemampuan teknis, kewirausahaan dan daya saing petani dan pemberdayaan dapat dimulai melalui penguatan kelembagaan lokal (Fonchingong dan Fonjong, 2003; Ofuoku dan Isife, 2009; Schmidt et al., 2015 dalam Wardani dan Anwarudin, 2018). Usman (2004), menyatakan bahwa strategi penting dalam pembangunan adalah pemberdayaan pada masyarakat. Pemberdayaan adalah satu kekuatan yang sangat vital. Kekuatan itu dapat dilihat dari aspek fisik, material, ekonomi, pendapatan, kelembagaan (tumbuhnya kekuatan individu dalam bentuk wadah/kelembagaan), kerjasama, intelektual, kekuatan komitmen bersama untuk mematuhi dan menerapkan prinsip pemberdayaan (Sunyoto, 2004 dalam Iryana, 2018).

Telah dibuktikan bahwa dibeberapa negara, penyuluhan yang memberdayakan petani mampu mengurangi kemiskinan di desa (Eastwood et al., 2017, Houser, et al. 2016 dalam Anwarudin, 2017). Pemberdayaan yang dilakukan tersebut mengedepankan partisipasi petani dalam setiap kegiatan dan program (Haoser et al., 2016 dalam Anwarudin, 2017). Dengan demikian kondisi perekonomian desa akan meningkat dan sangat menarik bagi generasi muda untuk tidak lagi pergi ke kota bahkan generasi muda yang telah bekerja di kota akan kembali ke desa.

\section{Inovasi Pekarangan Pangan Lestari (P2L)}

Pengertian inovasi secara singkat dapat didefinisikan sebagai sebuah proses baru yang menghasilkan produk baru, teknologi baru dan memiliki nilai tambah (United nations Development Programme, 2016 dalam Sutisna dan Martani, 2019). Inovasi yang bermanfaat mempunyai karakteristik antara lain: a) keunggulan relatif, yaitu tingkat sebuah inovasi dipersepsikan lebih baik dari ide inovasi sebelumnya; b) kesesuaian yaitu sebuah inovasi dipersepsikan sesuai dengan nilai-nilai yang ada, pengalaman masa lalu dan sesuai dengan kebutuhan orang-orang yang mempunyai potensi untuk mengadopsi; c) kerumitan, dimana tingkat sebuah inovasi dipersepsikan sulit untuk dipahami atau digunakan; d) ketercobaan, atau derajat sebuah inovasi dapat dieksperimentasikan pada lingkup terbatas dan e) keterlihatan dimana sebuah inovasi itu dapat 
terlihat oleh orang lain (Rogers, 2005 dalam

Ahmad, 2016)

Pekarangan bukan hanya menciptakan kesejukan dan keindahan, tetapi lebih dari itu adalah meningkatkan ekonomi keluarga. Jenisjenis tanaman bisa ditanam di pekarangan seperti, sayuran, tanaman obat, buah-buahan dan tanaman hias (Dwiratna et al., 2016). Dengan memanfaatkan lahan pekarangan berpotensi memenuhi kebutuhan keluarga (Mardiharini, 2011 dalam Ashari et al., 2012).

Dari uraian diatas, inovasi P2L atau yang dulunya bernama kawasan rumah pangan lestari (KRPL) memenuhi kriteria inovasi yang bermanfaat untuk dikembangkan di masyarakat. KRPL atau P2L adalah kegiatan Badan Ketahanan Pangan, Kemeterian Pertanian yang dimulai tahun 2010-2019 Sejak tahun 2020 berubah nama menjadi pekarangan pangan lestari (P2L). Kegiatan P2L dilaksanakan oleh kelompok masyarakat yang secara bersama-sama mengusahakan lahan pekarangan sebagai sumber pangan secara berkelanjutan. Program ini dilaksanakan untuk mendukung pemerintah dalam rangka penanganan daerah prioritas stunting atau penanganan daerah rentan rawan pangan. Dengan memanfaatkan lahan pekarangan, lahan tidur, lahan kosong yang tidak produktif untuk menghasilkan pangan dalam memenuhi pangan dan gizi rumah tangga yang berorientasi pasar selain itu dapat meningkatkan pendapatan keluarga. Kegiatan P2L akan menjadi contoh bagi rumah tangga dalam meningkatkan ketersediaan, aksesibilitas, pemanfaatan pangan yang bergizi, beragam, seimbang, aman dikonsumsi dan berorientasi pasar.

\section{KESIMPULAN}

Persoalan pangan adalah persoalan hidup mati suatu bangsa. Oleh karena itu, ada beberapa solusi yang dapat dilakukan seperti mengubah mindset generasi muda dimulai dari diri kita sendiri dengan memberi informasi yang benar bahwa pertanian itu menarik.

Dunia pertanian tidak hanya bercocok tanam yang identik dengan kotor, tapi ada cabang lain seperti peningkatan kualitas produk serta pemasaran hasil pertanian. Lembaga pendidikan dari TK-SMU wajib punya lahan untuk bercocok tanam dan guru yang membidangi pertanian.

Rekruitmen mahasiswa dari tiap desa potensi pengembangan pertanian dan pemberian beasiswa bagi calon peserta didik yang berprestasi namun secara finansial kurang mampu untuk didik dipoliteknik pembangunan pertanian dan politeknik enjinering pertanian.

Menggalakkan program mari membangun desa dan menyiapkan sarana dan prasarananya antara lain alat mesin pertanian, pengairan dan sumberdaya lahan diamping sumberdaya manusia yang handal. Mendorong pembentukan kelompok-kelompok masyarakat, pembinaan secara berkelanjutan dan terarah oleh pemerintah. Mendorong program P2L bagi setiap rumah tangga dan penyediaan sarana produksi yang mudah diakses

\section{DAFTAR PUSTAKA}

Ahmad, Y. (2016). Pengaruh karakteristik inovasi pertanian terhadap keputusan 
adopsi usaha tani sayuran organik. Journal of Agro Science, 6(2).

Anwarudin, O. 2017. Faktor penentu partisipasi petani pada Program Upaya Khusus (Padi) di Kabupaten Manokwari, Papua Barat. Jurnal Penyuluhan Pertanian. 12(1), 67-79.

Anwarudin, O., Sumardjo, S., Satria, A., \& Fatchiya, A. (2020a). Kapasitas kewirausahaan petani muda dalam agribisnis di Jawa Barat. Jurnal Penyuluhan, 16(2), 267-276.

Anwarudin, O., Sumardjo, S., Satria, A., \& Fatchiya, A. (2020b). Peranan penyuluh pertanian dalam mendukung keberlanjutan agribisnis petani muda di Kabupaten Majalengka. Jurnal Agribisnis Terpadu, 12(1), 17-37.

Anwarudin, O., Sumardjo, S., Satria, A., \& Fatchiya, A. (2020c). Proses dan pendekatan regenerasi petani melalui multistrategi di Indonesia. Jurnal Penelitian dan Pengembangan Pertanian, 39(2), 73-85.

Arvianti, E., Asnah, Y., \& Prasetyo, A. (2015). Minat pemuda tani terhadap transformasi sektor pertanian di Kabupaten Ponorogo. Jurnal Buana Sains, 15(2), 181-188.

Ashari, S., \& Purwantini, T.B. (2012). Potensi dan prospek pemanfaatan lahan pekarangan untuk mendukung ketahanan pangan. Forum Penelitian Agro Ekonomi, 30(1), 13-30.

Badan Pusat Statistik. (2014). Statistik Kepemudaan Indonesia. Jakarta: BPS.

Badan Pusat Statistik. (2020). Statistik Pemuda Indonesia. Jakarta: BPS.

Badan Pusat Statistik. (2020). Hasil Sensus Penduduk 2020. Jakarta: BPS

Chamber, R. (1988). Pembangunan Desa Mulai dari Belakang. Penerjemah: Pepep Sudrajat. LP3S. Jakarta.

Dwiratna, N.P.S., Widayasanti, A., \& Rahma, D.M. (2016). Pemanfaaatan lahan pekarangan dengan menerapkan Kawasan Rumah Pangan Lestari. Dharmakarya: Jurnal Aplikasi Iptek untuk Masyarakat, 5(1), 19-22.

Junaedi J. A., Anwarudin, O., \& Makhmudi, M. (2020). Dinamika kelompok tani terhadap minat generasi muda pada kegiatan usaha tani padi (Oriza sativa $L$ ) di Kecamatan Gantar Kabupaten Indramayu. Jurnal Inovasi Penelitian, 1(3), 501-511.
Harun, R., \& Ardianto, E. (2011). Komunikasi Pembangunan dan Perubahan Sosial. Rajawali Pers. Jakarta. hlm 344.

Iryana, A.B. (2018). Pemberdayaan masyarakat petani dalam meningkatkan kesejahteraan hidup di Kecamatan Compreng Kabupaten Subang. Jurnal Academia Praja, 1(2).

Kementerian Pertanian. (2015). Rencana Strategis Kementerian Pertanian Tahun 2015-2019. Kementerian Pertanian Republik Indonesia. Jakarta.

Kementerian Pertanian. (2020). Statistik Ketenagakerjaan Sektor Pertanian. Pusat Data dan Informasi Pertanian, Sekretariat Jendral. Kementerian Pertanian. Jakarta.

Khuzaeva. S. E. (2014). Mengembangkan pola pikir cerdas, kreatif dan mandiri melalui telematika. Jurnal Lingkar Widyaiswara, 1(4), 138-148.

Makabori, Y. Y., \& Tapi, T. (2019). Generasi muda dan pekerjaan di sektor pertanian : faktor persepsi dan minat (studi kasus mahasiswa Politeknik Pembangunan Pertanian Manokwari). Jurnal Triton, 10(2), 1-20.

Ningsih, F. \& Sjaf, S. (2015). Faktor-faktor yang menetukan keterlibatan pemuda di pedesaan pada kegiatan pertanian berkelanjutan. Jurnal Penyuluhan, 11(1).

Nazaruddin, N., \& Anwarudin, O. (2019). Pengaruh penguatan kelompok tanitterhadap partisipasi dan motivasi pemuda tani pada usaha pertanian di Leuwiliang, Bogor. Jurnal Agribisnis Terpadu, 12(1), 1-14.

Rosana. E. (2011). Modernisasi dan Perubahan Sosial. Jurnal TapIs, 7(12).

Setiawan. I. (2015). Strategi pengembangan kemandirian pelaku muda agribisnis "brain gain actors" di Jawa Barat. Mimbar, 31(2), 409-418.

Sutisna. J.A \& Husaini, M. (2019). Dua faktor penentu keberhasilan sebuah proses inovasi. Inovbiz: Jurnaal Inovasi Bisnis. 7(1): 1-7.

Virianita, R., Soedewo, T., Amanah, S., \& Fatchiya, A. (2019). Persepsi petani terhadap dukungan pemerintah dalam penerapan sistem pertanian berkelanjutan. Jurnal Ilmu Pertanian Indonesia (JIPI), 24(2), 168-177.

Wardani \& Anwarudin, O. (2018). Peran penyuluh terhadap penguatan kelompok tani dan regenerasi petani di Kabupaten 
Bogor Jawa Barat. Jurnal Tabaro, 2(1), 191-200.

White, B. (2011). Who will Oun The Country Side? Disspossession, Rural Youth And The Future of Farming. International Institute of Social Studies (internet) dapat di unduh dari http://pustaka.litbang.go.id

White, E. G. (2005). Dasar-Dasar Pendidikan. Indonesia Publishing Hause. Bandung. 